\title{
EU har trukket \\ Europa ud af krisen
}

Af Connie Hedegaard

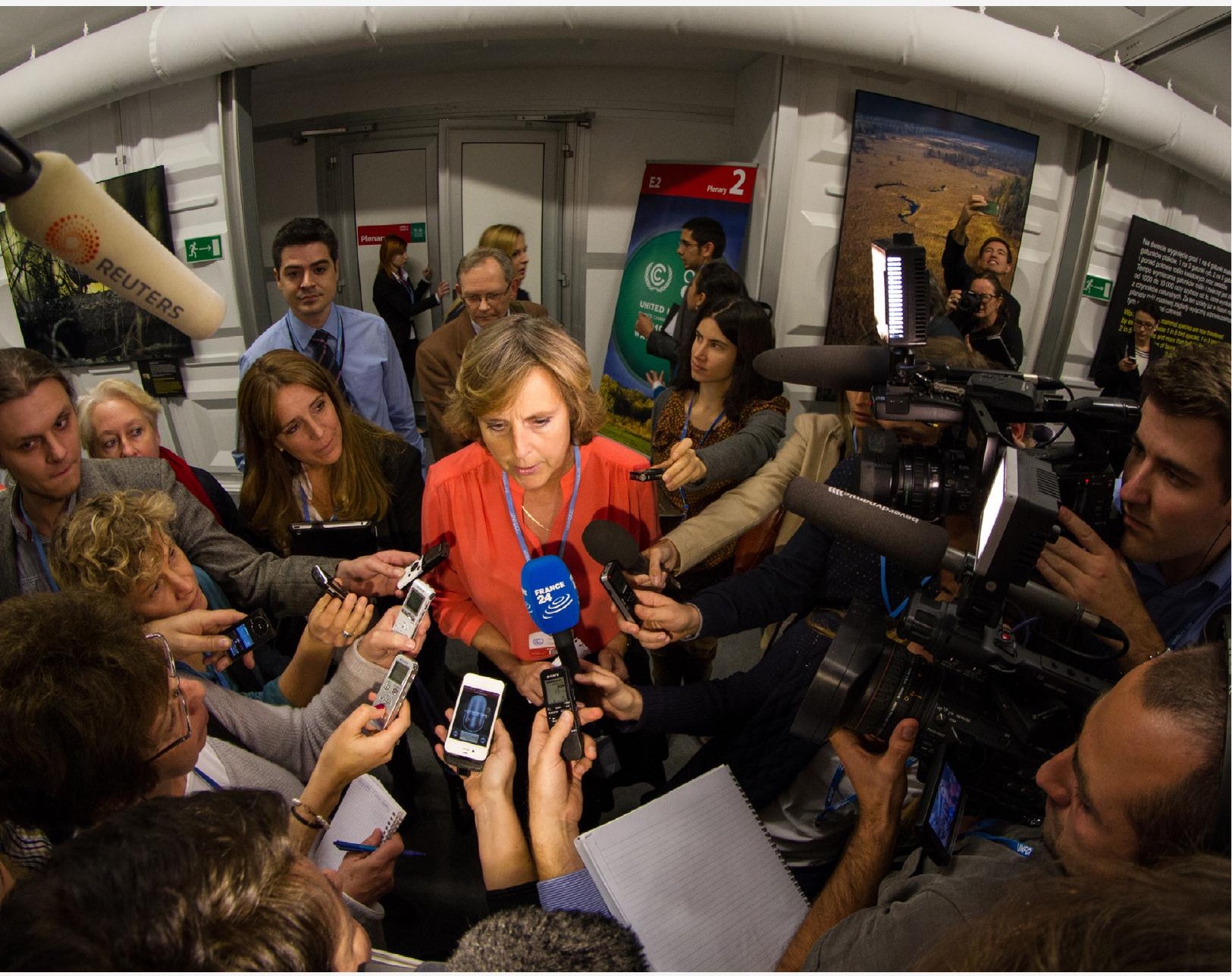


Den gode nyhed er, at vi rent faktisk er på vej ud af krisen. Men krisehåndteringen har kostet alvorligt på tilliden til EUsystemet. Bruxelles skal blive bedre til at kommunikere beslutningerne, og så skal man minde en ny generation om perspektivet i EU.

Økonomi, økonomi og én gang til økonomi. Det er den korte fortælling om Barroso II-kommissionens embedsperiode. Selvfølgelig er der også mange andre områder, vi som Europa-Kommission har håndteret, blandt andet energi og klima, som jeg selv har ansvaret for. Men det har i den grad været økonomien, der har været det dominerende. Og det nødvendige fokus har haft omkostninger i forhold til, hvor EU står i dag i borgernes øjne.

Denne Kommission tiltrådte i februar 2010. Og hvis man går tilbage til avisoverskrifterne fra den tid kan man se, at på det tidspunkt forestillede ingen sig, at vi først hen mod slutningen af vores mandat, ville kunne se lyset for enden af tunnelen.

Ganske vist var Europa i dyb recession med negativ BNP-vækst på 4,5 pct., men der var en klar forventning om snarlig vending i økonomien. Også i det kriseramte Grækenland, hvor Kommissionen vurderede, at Grækenland kunne være ude af det økonomiske morads hen mod 2012.

Men som Kierkegaard siger, livet leves forlæns, men forstås baglæns. Og vi kan bare konstatere, at økonomerne tog fejl. For tænk, hvad vi har været igennem siden. Det frygtede double dip indfandt sig, og det ramte særligt hårdt i Grækenland, Spanien, Portugal, Irland og Cypern. Så snart vi fik løst det ene af problemerne, dukkede der nye op. Så sent som sidste år var udviklingen særdeles alvorlig i Cypern. Og så har jeg slet ikke nævnt dem, der har bevæget sig på kanten af noget overordentlig alvorligt, bl.a. Italien og Frankrig.

Hvis man skal gøre omfanget af krisen konkret, kan man tænke tilbage på søndag 2. maj 2010. Kort tid efter vi var tiltrådt, blev Kommissionen indkaldt til møde søndag eftermiddag, og det er langt fra almindeligt, at det sker. Og det blev fulgt op samme aften af et ekstraordinært møde i eurogruppen, der sammen med Kommissionen, IMF og den Europæiske Centralbank fik rejst et tre-årigt låneprogram på $80 \mathrm{mia}$. euro eller $600 \mathrm{mia}$. kroner til Grækenland.

Der blev ikke lagt skjul på alternativet, for hvis ikke beslutningerne blev taget den weekend, ville der være stormløb på bankerne, når de åbnede mandag morgen, Grækenland kunne være gået bankerot - med ganske alvorlige følger ikke bare for Grækenland, men også for resten af Europa.

Den økonomiske krise opstod ikke på grund af Europa. Den økonomiske krise opstod heller ikke på grund af euroen. Den begyndte i USA, og der var mange forskellige årsager til, at den udviklede sig, som den gjorde i de europæiske lande. Men det var EU's ansvar at håndtere krisen. Og det har EU gjort.

\section{Lang række tiltag}

Kommissionen har siden 2010 iværksat en lang række tiltag, der alle har til formål at sikre sunde offentlige finanser i medlems-

Connie Hedegaard er EU-kommissær med ansvar for klimabeskyttelse. Forinden var hun miljøminister og klima- og energiminister, og hun var i en årrække folketingsmedlem for Det Konservative Folkeparti. Hun har arbejdet som journalist, studievært og chef for Radioavisen. 
landene og dermed skabe grobund for vækst og jobskabelse. Man kan bl.a. nævne:

Det Europæiske semester giver Kommissionen mulighed for at analysere medlemsstaternes økonomiske politiker og komme med reformforslag, der sikrer balance i statskasserne.

Six Pack'en styrker Stabilitets- og Vækstpagten ved bl.a. at skærpe kravene til at holde budgetunderskud på max 3 pct. og offentlig gæld på max 60 pct. af BNP.

Finanspagten er nu implementeret $i$ alle lande undtagen i Storbritannien og Tjekkiet. Danmark gik også med, og det er ganske interessant, at det kunne lade sig gøre uden større debat. Finanspagten stiller strammere krav til nationale budgetter og giver mulighed for sanktioner, hvis ikke budgetdisciplinen bliver overholdt.

Sidste år kom Two Pack'en, som er et supplement til six packen, og den indfører endnu strammere kontrol med eurolandenes budgetter.

Endelig kan man også nævne aftalen om en bankunion, der efterhånden er vedtaget flere elementer af. Den sikrer, at kriseramte banker ikke sætter økonomien over styr i et ellers nogenlunde økonomisk sundt land som for eksempel Spanien. Og den skal forhindre, at skatteyderne kommer til at betale for risikable bankforretninger.

Man bør også nævne redningspakkerne ESM og EFSF, som har ydet lån til Grækenland, Irland, Portugal, Spanien og Cypern. Redningspakkerne har været meget omdiskuterede, men jeg mener, at de er udtryk for solidaritet mellem eurolandene, og de har reddet mange EU-borgeres job, samtidig med at de har stabiliseret den økonomiske situation i mange lande.

Samlet set skal pakkerne og initiativerne ses som en reaktion på de gigantiske gældsposter, som en række EU-lande havde oparbejdet i "de gode år” i 00’erne. Gældsbjergene havde udviklet sig til en alvorlig trussel mod Europas økonomi, og det har derfor været nødvendigt at ændre fundamentalt på det finanspolitiske samarbejde - det samarbejde, der ligger til grund for euroen.

Det kan være nemt nok nu at se, hvad der burde være blevet gjort for 10 år siden, da man etablerede euro'en. Men ikke desto mindre, var det altså ikke det, man gjorde. Og det er bare sådan i politik - det er også sådan i økonomi - at det man undlader at gøre, det har også en pris. Nu har vi på den hårde måde fået den grundlæggende struktur på plads.

Samtidig har vi i Kommissionen været bekymret for, om regeringerne, der jo gerne vil genvælges, ville have det politiske mod til ikke at give op på halvvejen. For det ville jo nærmest være det værst tænkelige, hvis man iværksatte alle de hårde tiltag, men så pludselig blev bange for den modstand man mødte undervejs og gav op, hvorefter man ikke ville have fået gennemført de nødvendige reformer. Samtidig ville borgerne opleve, at de havde været igennem hårde tider til ingen verdens nytte.

\section{Balancen}

Jeg er klar over, at man kan diskutere balancen. Det har vi naturligvis også gjort i Kommissionen. Men holdningen var klar: det er helt afgørende, at Europa nu får brugt krisen til at lave de nødvendige reformer.

Desværre har vi stadig en høj arbejdsløshed på 11 pct. i Europa, mens budgetunderskuddet for de samlede EU lande er reduceret fra 6,5 pct. i 2010 til nu 3,9 pct., så på den måde går det fremad. Og der er nu en svag vækst i EU's samlede bruttonationalprodukt - meget svag vækst, men der er vækst, hvor det altså var minus på 4,5 pct. for fire år siden. Irland er kommet ud af sit hjælpeprogram. Spanien er ude af hjælpepakken til den finansielle sektor. Portugal er på rette spor og kan afslutte sit låneprogram her $\mathrm{i}$ maj. Grækenland er i fremgang på en række parametre, men der er selvfølgelig stadig et stykke vej til sunde finanser.

Jeg lagde mærke til, da Nobelprismodtageren i økonomi Paul Krugman var i Køben- 
Personligt mener jeg, at det er vanvittigt vigtigt, at man kommunikerer klart om, hvad EU kan gøre, og hvad EU ikke kan gøге.

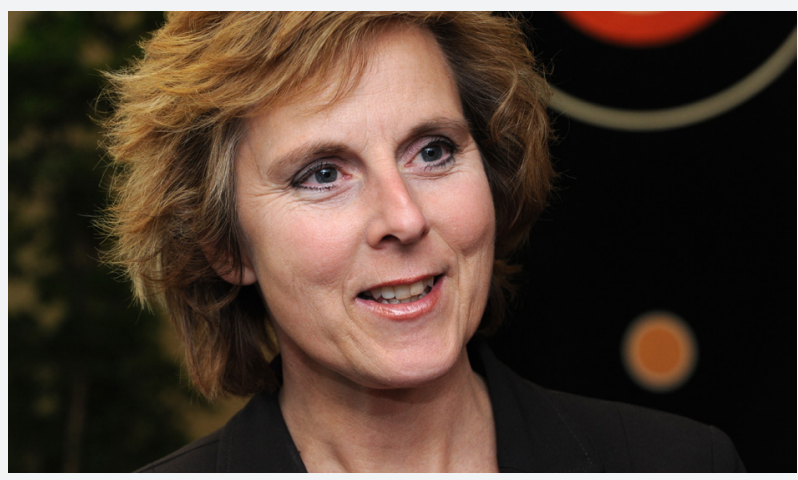

FOTO: [DEUROPEAN UNION, 2014

havn for et par måneder siden, så medgav han rent faktisk, at han aldrig i sin vildeste fantasi havde tiltroet, at EU ville have den politiske beslutningskraft, der skulle til for at præstere det nødvendige. $\mathrm{Nu}$ er han jo ikke ligefrem en mand, der er kendt for at strø om sig med ros, men grundlæggende anerkendte han faktisk, at der er truffet ganske markante og fornuftige beslutninger.

I Kommissionen har vi ikke set det som et valg mellem enten hårde besparelser eller finanspolitiske lempelser. Selvfølgelig må dybt forgældede lande nedbringe deres gæld, og naturligvis skal vi bruge krisen til også at gennemføre hårdt tiltrængte strukturelle reformer. Men vi har samtidig advokeret for målrettede og fremtidsrettede investeringer på udvalgte områder som for eksempel infrastruktur og energi. Det har altså ikke været enten/eller. Det har været et både/og.

Vi har omdirigeret store summer i EU's strukturfonde. Vi har fået vedtaget et budget for de næste syv år, der markant øger bevillingerne til forskning, udvikling og innovation. Det er sådan set den eneste post, der for alvor øges, men det bør også bemærkes, at mindst 20 pct. af hele EU's nye 7 -års budget skal bidrage til at fremme vores klimamål og klimatilpasning. Det er en helt ny måde at tænke et budget på.

Samtidig har Den Europæiske Investeringsbank fåt ekstra midler til at hjælpe små- og mellemstore virksomheder ud af kreditklemmen, så der atter kan komme gang i de investeringer, der er forudsætningen for, at der skabes ny aktivitet og dermed nye job.

\section{EU's dilemma}

Men Kommissionens dilemma er, at mange af instrumenterne til jobskabelse og de tilhørende politikker ikke er EU kompetence, men nationale kompentenceområder. Derfor har vi oplevet, at flere af de tiltag, man på topmøderne har analyseret sig frem til, og som ville kunne bidrage med en hel masse på beskæftigelsesområdet, på de områder har EU reelt ikke kompetencen.

Personligt mener jeg, at det er vanvittigt vigtigt, at man kommunikerer klart om, hvad EU kan gøre, og hvad EU ikke kan gøre. Mange af de midler, der konkret skal bruges til at skabe job, de ligger ikke i EU. Det har blandt andre Danmark været med til at sikre, for man har ikke ønsket, at det skulle være EU's kompetence. Vi kan konstatere, at der har været et misforhold mellem, at krisen er blevet et EU-anliggende, men en del af midlerne til at løse den, har i den grad ligget nationalt.

Hvis vi skal prøve at konkludere på den økonomiske del, så vil jeg sige: ja, den økonomiske hestekur har været barsk for mange europæere, men der har ikke været nogen anden vej end at sikre balance i de offentlige budgetter. Alternativet ville have været øget usikkerhed om både job og velfærd. 
Et tættere finanspolitisk samarbejde etableres ikke med et fingerknips, men nu er byggestenene lagt. Ledetråden i Kommissionens økonomiske politik er, at hvis der skal mere økonomisk solidaritet i Unionen, skal der også følge stærkere ansvar for og kontrol med de offentlige budgetter.

EU skal afgjort, efter min opfattelse, ikke blande sig i alt. Men der er mange områder, hvor vi får bedre resultater, også økonomisk, hvis vi puljer vores kræfter. Fælles spilleregler for bankerne er et godt eksempel. Det er ganske vist "mere EU", men alternativet er, at bankernes excesser i ét land kan gå ud over borgerne i et andet. For den globale økonomi er blevet den helt store udfordring til politikerne i det 21. århundrede: økonomien, kapitalen og markedet operer globalt, mens de politikere, der (hvor det er nødvendigt) skal regulere markedet, de tænker i vid udstrækning stadig meget nationalt og endda ofte meget lokalt.

Samtidig med, at vi skulle håndtere de økonomiske problemer, har vi fået et andet stort udviklingsspor, nemlig globaliseringen af økonomien og hele det geopolitiske skifte med nye stærke økonomiske centre: Kina, Brasilien og andre, som er dukket op og har vokset sig meget stærke. Men det er jo ikke sket under krisen specielt, man kan måske tværtimod sige, at det var i de gode år før krisen, at vi burde have fundet ud af at, at der var et større geostrategisk skifte på vej. Vi er altså udfordret på en helt anden måde også konkurrencemæssigt, end vi plejer at være. Og det er dette dobbelte pres,som vi i virkeligheden har skullet operere i.

\section{Folket skal med}

Den gode nyhed er, at vi rent faktisk er på vej ud af krisen. Men i demokratiske samfund tager omstilling tid, og nye tiltag skal forankres, accepteres hos de borgere, politikerne repræsenterer. Her ligger en af de helt store udfordringer. For det er desværre ikke lykkedes at kombinere virkeligheden med et reelt begrænset råderum og samtidigt sikre den demokratisk livsnødvendige opbakning og accept hos borgerne.

Der har vitterligt været en del nødvendighed over de valg, der er blevet truffet. Nu hører jeg ikke til en af dem, der mener at politikere ikke altid har en eller anden grad af valg, men jeg kan sige, at vi har siddet i mange situationer, hvor der ikke rigtig var nogen lækre scenarier at vælge imellem. Men i politik skal man jo altså have folk og vælgerne med.

Jeg plejer at bruge min fortid som journalist ved DR som eksempel, hvor nogen ovenover én selv hele tiden laver store forkromede nye tiltag. Og hver gang de har fàet formidlet, at nu er de i gang med en ny stor reform - og man tænker: jamen så må vi vel gå i gang med det - så har reformen allerede været så længe undervejs på ledelsesplan, at lige så snart man begynder at implementere det som medarbejder, så kommer der straks noget nyt væltende. Og på et eller andet tidspunkt, mister folk lidt af interessen for det. Jeg tror, at I alle sammen kender det fra jeres egne sammenhænge. Men det er altså sindssygt vigtigt i demokratiske samfund, at der er tid til, at kursen forankres, konsolideres, at der kan skabes opbakning bag tiltagene. Den luksus har vi ikke haft.

Krisehåndteringen har kostet alvorligt på tilliden til EU systemet. Men gennem Eurobarometers spørgeskemaer kan vi se, at det har faktisk kostet endnu mere på tilliden til de nationale regeringer. Derfor er der en generel udfordring med tillid til det politiske. Og der er mange årsager til, at det er blevet sådan. For det første er det jo elementært at konstatere, at der i forhold til EU mangler en europæisk offentlighed. Det vil sige fælleseuropæiske medier, fælles kommunikationskanaler. Det meste af den kommunikation, som når de enkelte borgere om fælleseuropæiske beslutninger eller mangel på samme, kommer fra nationale medier via nationale politikere, der af 
forståelige - men ikke desto mindre ulyksalige grunde - har en tendens til at gøre et fjernt EU til syndebuk for upopulære beslutninger, mens vindersagerne ofte tillægges den eminente nationale indsats. Det ville være dejligt, hvis man sagde, at Danmark var en undtagelse, men det ville ikke være retvisende.

I Danmark siger vi ofte, at vi skal være så tæt på kernen i EU som muligt. Men hvordan får man borgernes opbakning til det, hvis EU-debatten hele tiden foregår, som debatten har foregået det sidste års tid? Lakridspiber - lad dem hvile i fred - der har aldrig været tale om at forbyde dem. Kanelsnegle - ja det var så den danske implementering, den var gal med og sådan set ikke EU. Kvindekvoter - det kan være et meget godt eksempel på, at EU måske skulle lade være med at blande sig i alt mellem himmel og jord. Men alle disse eksempler er ikke de vigtigste, selvom de jo efterlader et indtryk hos rigtig mange mennesker om, at EU er noget lidt underligt noget.

\section{Børnechecken}

Derimod vil jeg godt bruge debatten om børnechecken til at trække nogle større linjer op for, hvor problemet med den danske EU debat ligger. For børnechecken og velfærdsydelserne er et godt eksempel - man kan også sige det er et skidt eksempel - men det er i hvert fald et illustrativt eksempel. For eksempel så taler vi ikke om velfærds"problemer" eller velfærds-"udfordringer" eller velfærds-"niveauer"; lynhurtigt taler vi om velfærdsturisme. George Orwell kunne ikke have gjort det bedre. Det er, som om vi - Danmark, danskerne - er blevet påduttet noget af "dem dernede". Vi er ofre. Ofre for Kommissionen, for Domstolen, for "ansigtsløse bureaukrater". Hvem der er hvem, det kommer sig ikke så nøje - men det er i hvert fald nogen nede i Bruxelles eller deromkring: og de vil trække noget ned over hovedet på os. At det så har været kendt siden 1958, 1971, 2004 og vedtaget $\mathrm{i}$ enighed under den tidligere re- gering i 2009 - det kommer sig heller ikke så nøje. Facts forstyrrer ikke alt for meget. Tag bare Jyllands-Posten for nylig, hvor det jo viste sig - mærkeligt nok - at de her østeuropæere, vi har talt så meget om, de trækker sådan set mindre på de offentlige danske ydelser end gennemsnitsdanskeren og langt mindre end så mange andre grupper, der kommer hertil.

Betyder det så, at jeg ikke synes, at der er problem? Nej, det betyder det ikke. Der er et problem! Og det handler ikke så meget om økonomi, som det handler om politik, og det handler om, hvad folk opfatter som fair eller ikke fair. Mit bud er: jamen, så find en løsning. Tag det op i stedet for at skyde skylden på EU, når det er danske partier og skiftende danske regeringer, der selv har støttet de eksisterende love, som de der "ansigtsløse bureaukrater" nu prøver at forvalte så godt, som de kan. Man har været alt for længe om at håndtere problemet, selv om alle kunne se, at det kom. Det har man kunnet se i mange måneder, halve eller hele år.

Men grunden til, at jeg nævner dette eksempel er, at det har en langtidsvirkning for EU-debatten i Danmark, som er rigtig skidt. For selv hvis man nu får det løst - og det kan vi jo håbe på, at man gør - så er det selvfølgelig rigtig skidt på den korte bane, at de EU-positive partier ikke har gjort sig mere umage i tide. For på den måde har de EU-positive partier i samdrægtighed sikret sig, at dem, man var mest uenige med, de tjener mest på forløbet. Det er paradoksalt. Og på den lange bane er prisen, at det skaber en meget grundlæggende skepsis over for EU. Og hvis man vil være tættere på kernen, har man jo brug for befolkningens grundlæggende opbakning.

\section{Ikke kun Danmark}

Er det kun Danmark og den danske debat, der har svigtet? Nej, jeg mener at Bruxelles inklusiv Kommissionen skal være dygtigere til at kommunikere beslutningerne. Tale med borgerne, tale til borgerne, og kommu- 
nikere, hvad man gør. Og jeg mener også, at man i EU skal være dygtigere til at signalere - og også i det daglige virke - vise, at man godt ved, at EU ikke skal blande sig i alting. Vi har haft store diskussioner - også i denne Kommissions tid - om hvorvidt EU skal brede sig mere og mere, eller om man ind imellem skal holde tilbage og respektere subsidiaritet og andre gode principper. Resultatet af de diskussioner, kom blandt andet i Barrosos State of the Union-tale sidste efterår, da han sagde, at EU skal være "small on small things, big on big things". Og så vil jeg tilføje, at EU får kun lov af borgerne til at være "big on big things", hvis man ikke er "big on small things". Det skal man være meget bevidst om.

\section{Det store perspektiv}

Endelig vil jeg opfordre til, at man også minder en ny generation om det lidt større perspektiv i EU. For når vi har de der enkeltsager, er det meget nemt at se, hvor fuldstændig tåbelige de er. Men der er altså brug for at trække linjerne op. Fra den generation, hvor EU blev set som fredens projekt; fra den generation i 80'erne, hvor det indre marked var en drivende kraft; fra min generation, hvor det var udvidelsen og Murens fald, der var det utrolige. Tænk hvis Østeuropa i dag ikke havde EU medlemsskabet, tænk hvis de ikke havde NATO-medlemsskabet. Tænk også over, at Polens BNP i dag er tre gange Ukraines - for 25 år siden lå de stort set på niveau. Der må være et eller andet, som vi gør rigtigt i EU.

Tænk, at Balkanlandene står i kø - selv de yngste her på universitetet har levet, mens der var krig på Balkan. Tænk, at EU er forenet. Kommissionens formand Barroso blev politisk aktiv under Nellike-revolutionen i midten af 1970'erne i Portugal. Nogle kan huske, da Kronprinsesse Margrethe skulle giftes og man ikke kunne være sikker på, at eks-kong Konstantin og søster Anne-Marie kunne komme med, fordi der var sket et militærkup i Grækenland.

Min pointe er bare at sige, livet i Europa har aldrig været let. Men vanskelighederne er altså ikke kommet med EU. Faktisk har EU skånet os for endnu flere vanskeligheder, og man har løst krisen. Det er naivt, hvis vi tror, at opspind og renationalisering er opskriften på at gøre EU stærkere. Også i forhold til det geostrategiske billede, der tegner sig af verden i det 21. århundrede.

Men EU må udvise selvdisciplin, og i Danmark må vi tale om at håndtere $\mathrm{EU}$ som det ,det er: en almindelig politisk kampplads. På sådanne kamppladser sker de underligste ting. Og der bliver foreslået de mærkværdigste ting. Det, man ikke kan lide, må man så bekæmpe. Og det er Danmark faktisk ret god til. Danmark er god til at præge og påvirke. Tænk om det nationale politiske niveau påtog sig at bringe indflydelsen og mulighederne for indflydelse, fingeraftrykkene som vi rent faktisk sætter, i centrum for den offentlige debat. Hvis vi altså i højere grad kunne tale om, at hvad der sker i Europa, det er også vores ansvar. EU er ikke de andre. EU - det er faktisk også os.

Artiklen er en redigeret version af en tale, som Connie Hedegaard holdt 31. Marts 2014 på en EU-konference, arrangeret af bl.a. Det Udenrigspolitiske Selskab og Københavns Universitet. 